\title{
Statyba
}

\section{SIMILARITY BETWEEN ACOUSTIC INDICATORS OF AN REAL HALL AND ITS MODEL}

\section{J. Stauskis}

To cite this article: V. J. Stauskis (1999) SIMILARITY BETWEEN ACOUSTIC INDICATORS OF AN REAL HALL AND ITS MODEL, Statyba, 5:1, 68-73, DOI: 10.1080/13921525.1999.10531435

To link to this article: https://doi.org/10.1080/13921525.1999.10531435

曲 Published online: 26 Jul 2012.

Submit your article to this journal ¿

III Article views: 34 


\title{
REALIOS SALĖS IR JOS MODELIO AKUSTINIU RODIKLIŲ PANAŠUMAS
}

\author{
V. J. Stauskis
}

\section{Ivadas}

Salių akustikos skaičiavimo metodai dar nèra tokie tobuli ir prieinami daugeliui projektuotojuc kad būtu galima tiksliai ìvertinti būsimos salès akustines savybes. Tai ypač liečia muzikinès paskirties sales, kurių akustika yra sudetingiausia.

Vertinant salių akustiką visada būtina nustatyti vieną iš pagrindinių objektyvių akustinių parametrų - reverberacijos laika. Tai galima padaryti taikant plačiai pasaulyje naudojamą skaičiavimų metodą, kurio pagrindus šio šimtmečio pradžioje padejo W. Sabine [1]. Jis pasiūlè formule reverberacijos laikui apskaičiuoti. Šią formulę patobulino C. F. Eyringas [2] ir Millngtonas [3]. Formulès galioja tik esant difuziniam garso laukui. Tačiau jos neivertina salès formos, garsa absorbuojančių medžiagu išdesstymo vietų, tiesioginio garso savybiuc, klausytojo atstumo iki garso šaltinio, garso bangu difrakcijos, bangu interferencijos, oro tūrio rezonansu, pasikartojančiu aidų ir kt. Reverberacijos laikas, apskaičiuotas pagal šias formules, yra nekintamas visose salès vietose. Tačiau yra žinoma, kad išmatuotas reverberacijos laikas yra skirtingas ivairiose sales vietose. Jo kitimui didelę itaką turi salès forma, skirtingos garsą absorbuojančių medžiagų akustinès charakteristikos, jų išdèstymo vietos, atstumas iki garso šaltinio, garso lauko difuziškumas, pasikartojantys aidai ir kt. [4]. Tokiu atveju apskaičiuotas reverberacijos laikas nuo išmatuoto gali skirtis 2-4 kartus [5].

Todel formuojant salių akustiką būtini matavimai. Projektavimo stadijoje juos galima atlikti tyrimams naudojant fizinị salès modeli. Jo mastelis gali būti nuo 1:10 iki 1:50. Tyrimais modelyje galime nustatyti salès formos, garsą absorbuojančių medžiagu išdéstymo vietu, garso koncentracijos, pasikartojančių aidų ir kitų faktorių įtaką objektyviems ir subjektyviems salès akustiniams rodikliams, Skaičiavimais tokiu faktoriu itakos nustatyti praktiškai nę̨manoma.

Darbo tikslas - eksperimentais nustatyti realios salès ir jos modelio pagrindiniy akustinių rodikliu panašumus ir ivertinti ju skirtumus.

\section{Tyrimų objektas}

Tyrimams pasirinkta Lietuvos nacionalinès filharmonijos mažoji koncertų salè. Jos planas ir pjūvis pavaizduoti 1 paveiksle. Toki pasirinkimą lèmé tai, kad ši salè yra paprastos stačiakampio formos ir jos modeli padaryti yra lengviausia. Realios salès, kurios plano ir pjūvio forma yra sudétinga, o
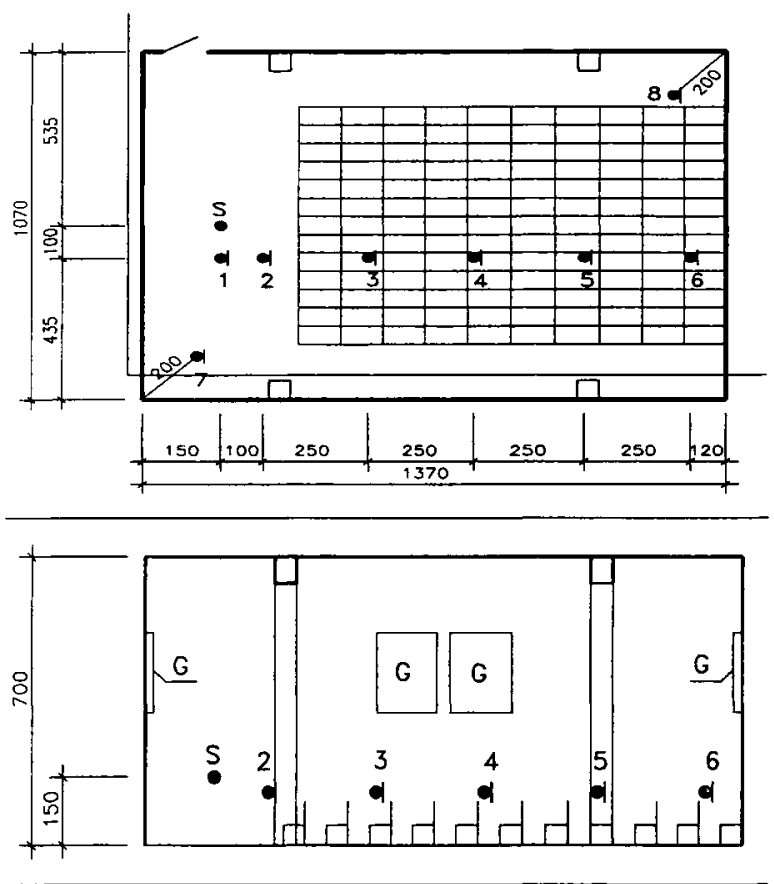

1 pav. Tiriamos salès planas ir pjūvis su tyrimo tašku išdèstymu

Fig 1. The plan and longitudinal section of the hall under investigation with the allocation of measurement points 
paviršiu plokštumos yra iš ivairios formos ir matmenų struktūrinių elementu̧, modelị padaryti yra labai sunku.

Salès lubos ir grindys yra horizontalios. Sienos - tinko, grindys - parketo, o lubos - iš dažytu gelžbetoniniu plokščių. Saleje yra vienas langas ir trejos durys. Taigi visi salès paviršiai yra iš gerai garsą atspindinčių medžiagu.

Salès modelio mastelis $1: 25$. Modelio grindys ir lubos padarytos iš tekstolito, o visos sienos iš $8 \mathrm{~mm}$ storio faneros, kuri buvo lakuojama tris kartus. Taigi modelio medžiagos pagal garso absorbcijos savybes yra artimos realios salès medžiagoms. Tai yra svarbu tiriant realios sales ir jos modelio akustinių rodikliu panašumą.

\section{Tyrimy metodika}

Tyrimams realioje salëje kaip garso šaltinis buvo panaudotas 9-to kalibro garsinis pistoletas. 1/2‘ mikrofonas itaisytas taške Nr. 3. Garsinis signalas per stiprintuvą ir keitikli analogas-kodas buvo irašomas i kompiuterio atminti ir po to $50-5000 \mathrm{~Hz}$ dažniu diapazono signalas analizuojamas pagal mūsų sukurtą akustinių signalų analizès programą. Taip buvo apskaičiuoti pagrindiniai objektyvūs ir subjektyvūs salès akustiniai rodikliai.

Tyrimams sales modelyje buvo panaudotas kibirkštinis garso šaltinis, kuris išspinduliuodavo tiek garsinius, tiek ir ultragarsinius signalus. Modelio šaltinis buvo iškišamas pro skylę grindyse tam, kad pagerètų spinduliavimo kryptingumo diagrama. Šaltinio ir $1 / 4^{\mathrm{c}}$ mikrofono padetys realioje saleje ir jos modelyje buvo tos pačios. Signalas iš mikrofono buvo paduodamas i stiprintuva iš jo i specialiai pagamintą keitikli analogas-kodas ir užrašomas i kompiuterio atmintị. Signalas gali būti ịrašytas per kelis skirtingus buferius, kurie leido keisti signalo įrašymo trukmę. Esant modelio masteliui 1:25 tiriamu dažnių diapazonas siekè nuo 1250 iki $50000 \mathrm{~Hz}$. Signalo diskreditavimo dažnis buvo $166,6 \mathrm{kHz}$, o diskreditavimo laikas - $6 \mathrm{mks}$. Grafikuose visi dažniai buvo perskaičiuoti i natūrinius.Viršutinè dažnių riba modelyje buvo apribota $2000 \mathrm{~Hz}$ tam, kad Naikvisto dažnis būtų didesnis už 3 .

Realiai salei ir jos modeliui lyginsime nefiltruoto signalo reverberacijos laiko reikšmes, aprok- simuojant garso lauko slopimą nuo 0 iki $-10,-20$, $-30,-35$ ir nuo $-5 \mathrm{iki}-35$, nuo $-15 \mathrm{iki}-25$, nuo -20 iki -30 ir nuo $-25 \mathrm{iki}-35 \mathrm{~dB}$, filtruoto signalo reverberacijos laiko reikšmes, absorbcijos koeficientus, bendrają absorbciją ir subjektyvius rodiklius.

\section{Tyrimų rezultatai}

2 paveiksle pavaizduota, kaip slopsta nefiltruoto signalo energija realioje saleje ir jos modelyje.

Grafikas rodo, kad garso lauko slopimas yra beveik vienodas per pirmas ir paskutines $400 \mathrm{~ms}$, t. y. ankstyvuoju ir vèlyvuoju slopimo periodu. Tarpiniu laiko intervalu, apytikriai nuo 500 iki $3000 \mathrm{~ms}$, garso lauko slopimas modelyje yra didesnis negu realybejje. Tačiau tas skirtumas yra nedidelis ir siekia tik $1-3 \mathrm{~dB}$. Šie rezultatai rodo, kad realioje salèje iki $2500 \mathrm{~ms}$ garso lauko slopimas yra visiškai artimas tiesei, o tai reiškia, kad laukas yra beveik difuzinis. Tuo tarpu salès modelyje garso lauko slopimas visiškai artimas tiesei tik iki $1000 \mathrm{~ms}$ ir jis slopsta greičiau negu realybejje. Tolesnis lauko slopimas turi kreivès pobūdi ir lauko difuziškumas pablogeja. Šie rezultatai rodo, kad garso lauko slopimas realioje salëje ir jos modelyje yra visiškai artimi.

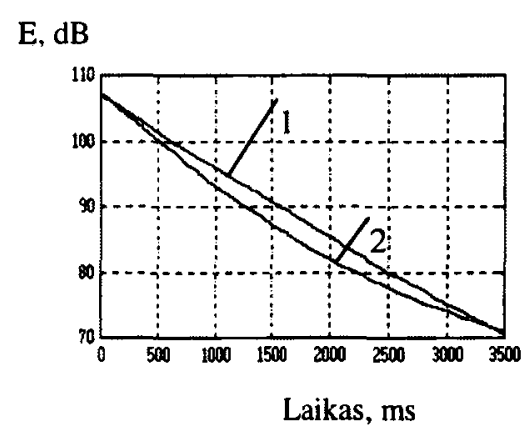

2 pav. Garso energijos slopimas realioje salèje (1) ir jos modelyje (2)

Fig 2. The decrease of the sound energy in the real hall (1) and its model (2)

Daug akustinès informacijos gali duoti nefiltruoto signalo reverberacijos laiko reikšmès realioje salèje ir modelyje, kada lauko slopimas yra aproksimuojamas skirtingais lygio slopimo intervalais. Tyrimų rezultatai pateikiami 3 paveiksle. 


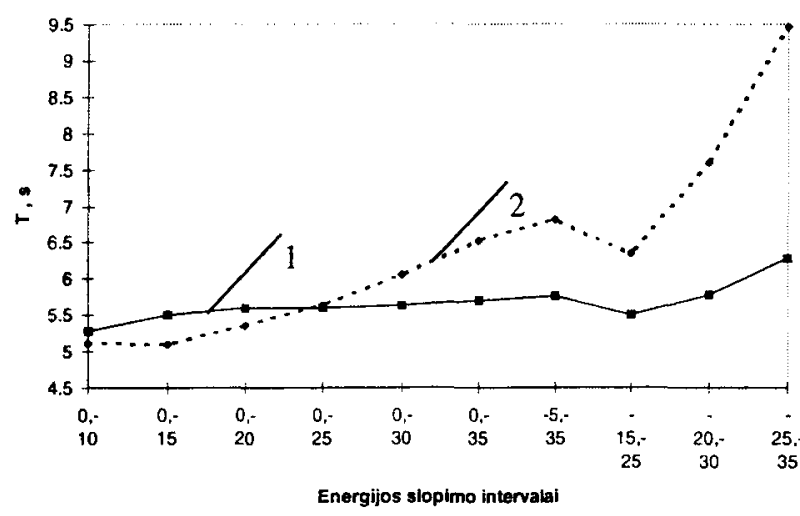

3 pav. Nefiltruoto signalo reverberacijos laiko priklausomybè nuo ivertintu garso lauko slopimo intervalų realioje saleje (1) ir jos modelyje (2)

Fig 3. The dependence of the reverberation time of a nonfiltred signal with estimate decrease intervals in the real hall (1) and its model (2)

Realios sales garso lauko slopimas yra artimas tiesei tol, kol lygio slopimas aproksimuojamas kas $10 \mathrm{~dB}$ nuo $0 \mathrm{iki}-35 \mathrm{~dB}$. Tai rodo, kad realios salès garso laukas yra difuzinis. Panaši padetis yra ir tada, kai slopimo pradžią imame nuo -15 ir $-20 \mathrm{~dB}$. Ir tik aproksimuojant slopimą nuo $-25 \mathrm{iki}-35 \mathrm{~dB}$, reverberacijos laikas gaunamas kiek didesnis. Tai rodo, kad vèlyvuoju slopimo periodu garso lauko difuziškumas pablogèja.

Analizuojant salès modelio garso lauko slopimą skirtingais intervalais matome, kad rezultaty sutapimas su realia sale yra labai geras, kai slopimas yra aproksimuojamas kas $10 \mathrm{~dB}$ nuo $0 \mathrm{iki}-30 \mathrm{~dB}$. Reverberacijos laiko skirtumas siekia $0,16-0,5 \mathrm{~s}$ ir yra mažesnis negu $10 \%$. Aproksimuojant lauko slopimą nuo -5 iki $-35 \mathrm{~dB}$ modelyje reverberacijos laikas gaunamas didesnis negu realioje saleje apie $1 \mathrm{~s}$, ir tai sudaro apie $15 \%$. Laikoma, kad rezultaty nesutapimas $10-15 \%$ yra labai mažas. Kiek didesnis rezultatu nesutapimas gaunamas tik vèlyvuoju garso lauko slopimo periodu. Tačiau tai nèra taip svarbu, nes pagrindiniai objektyvūs rodikliai yra nustatomi aproksimuojant lauko slopimą iki -30 ar $-35 \mathrm{~dB}$.

Tyrinejant salių akustiką visada reikia žinoti, kokios yra objektyviu akustinių rodiklių dažninès priklausomybès skirtingais slopimo intervalais. 4 paveiksle pateikiamas realios sales ir jos modelio ankstyvojo reverberacijos laiko dažninè priklausomybè.

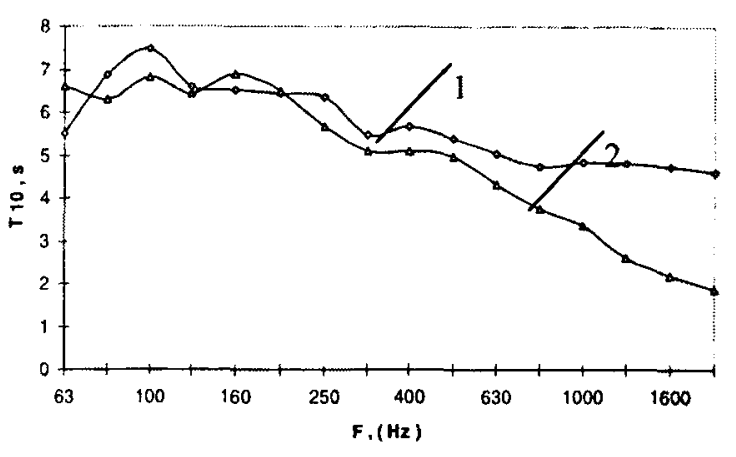

4 pav. Realios salès (1) ir jos modelio (2) reverberacijos laiko, aproksimuoto pagal garso lauko slopimą nuo 0 iki $-10 \mathrm{~dB}$, dažniné priklausomybè

Fig 4. The dependence of the reverberation time approximation of the sound decrease from 0 to $-10 \mathrm{~dB}$ in the real hall (1) and its model (2)

Rezultatai rodo, kad realios salès ir jos modelio ankstyvasis reverberacijos laikas net iki $500 \mathrm{~Hz}$ skiriasi nedaug $--0,2-0,8 \mathrm{~s}$. Toliau augant dažniui skirtumas vis labiau didèja. Tam realiausios itakos turi oro garso absorbcija modelyje. Tai yra todèl, kad dažniams, esant didesniems kaip $630 \mathrm{~Hz}$, modelyje jau gaunami ultragarsiniai dažniai, kuriụ bangos yra labai trumpos ir absorbcija ore yra labai aiški [6].

Visiškai panašūs rezultatai gaunami ir tada, kai garso lauko slopimas aproksimuojamas nuo 0 iki $-30 \mathrm{~dB}$. Rezultatai pateikiami 5 paveiksle.

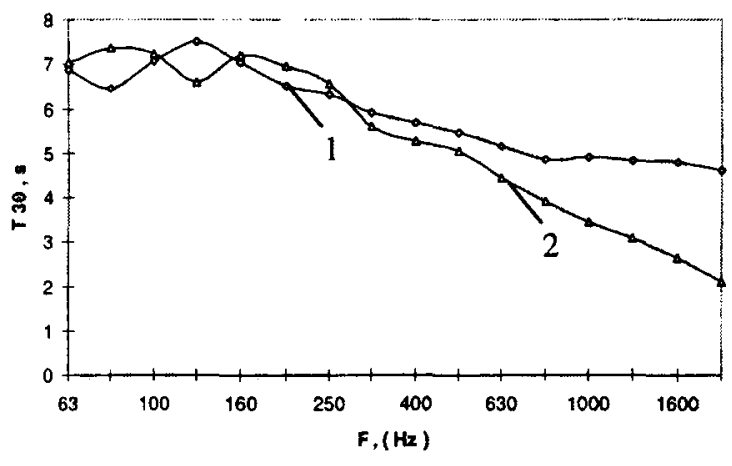

5 pav. Realios salès (1) ir jos modelio (2) reverberacijos laiko, aproksimuoto pagal garso lauko slopimą nuo $0 \mathrm{iki}$ $-30 \mathrm{~dB}$ dažninè priklausomybè

Fig 5. The dependence of the reverberation time approximation of the sound decrease from 0 to $-30 \mathrm{~dB}$ in the real hall (1) and its model(2) 
Ir šiuo atveju geri rezultatų sutapimai gaunami iki $500-630 \mathrm{~Hz}$. Dažnių intervalui esant iki $630 \mathrm{~Hz}$ realioje saleje ir jos modelyje reverberacijos laikai skiriasi mažiau kaip $1 \mathrm{~s}$, ir tai esant dviem dažniams, o tai sudaro tik apie $10 \%$. Didèjant dažniui reverberacijos laikai jau skiriasi gan stipriai ir tam itakos turi jau minèta garso absorbcija ore.

Standartinio reverberacijos laiko tyrimų rezultatai pateikiami 6 paveiksle.

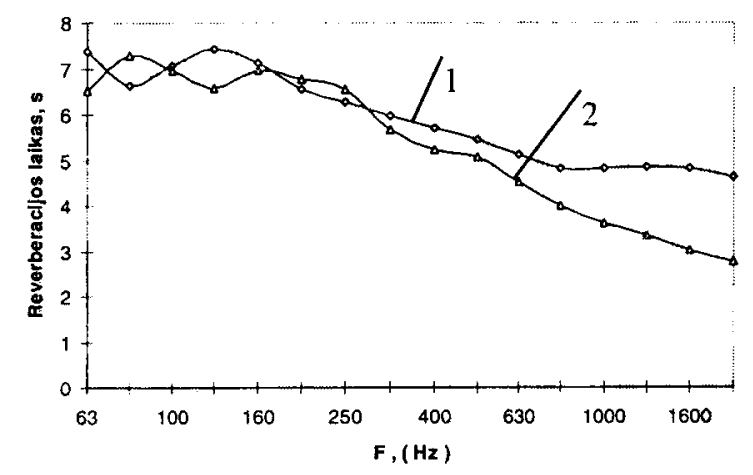

6 pav. Realios salès (1) ir jos modelio (2) reverberacijos laiko, aproksimuoto pagal garso lauko slopimą nuo $-5 \mathrm{iki}$ $-35 \mathrm{~dB}$, dažninè priklausomybè

Fig 6. The dependence of the reverberation time approximation of the sound decrease from -5 to $-35 \mathrm{~dB}$ in the real hall (1) and its model (2)

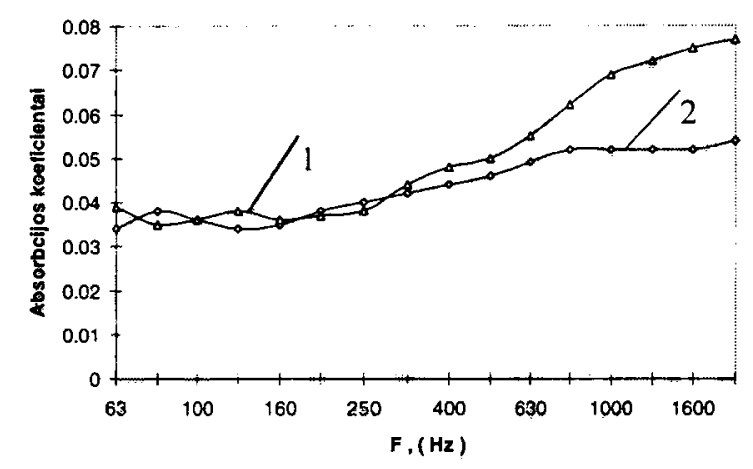

7 pav. Realios salès (1) ir jos modelio (2) garso absorbcijos koeficientu, apskaičiuoty iš reverberacijos laiko aproksimuojant garso lauko slopimą nuo $-5 \mathrm{iki}-35 \mathrm{~dB}$, dažninè priklausomybè

Fig 7. The dependence of the sound absorption coefficients calculated of the reverberation time approximation of the sound decrease from -5 to $-35 \mathrm{~dB}$ in the real hall (1) and its model (2)
Grafikas rodo, kad realios salès ir jos modelio standartinès reverberacijos reikšmès iki $500 \mathrm{~Hz}$ skiriasi nedaug. Šis skirtumas yra beveik toks pats, kaip ir aproksimuojant lauko slopimą nuo $0 \mathrm{iki}-10$ ir $-35 \mathrm{~dB}$. Rezultatai rodo, kad garso lauko energijos slopimas yra tolygus iki pat $-35 \mathrm{~dB}$.

Iš reverberacijos laiko reikšmiu apskaičiuoti realios salés ir jos modelio garso absorbcijos koeficientai ir bendroji garso absorbcija. Rezultatai pateikti 7 ir 8 paveiksluose.

Realios sales ir jos modelio garso absorbcijos koeficientai yra beveik vienodi dažnių diapazonui esant iki $500-630 \mathrm{~Hz}$. Didejant dažniui skirtumas dideja, nes pasireiškia didelè garso absorbcija ore.

Garso absorbcijos kitimas pavaizduotas 8 paveiksle.

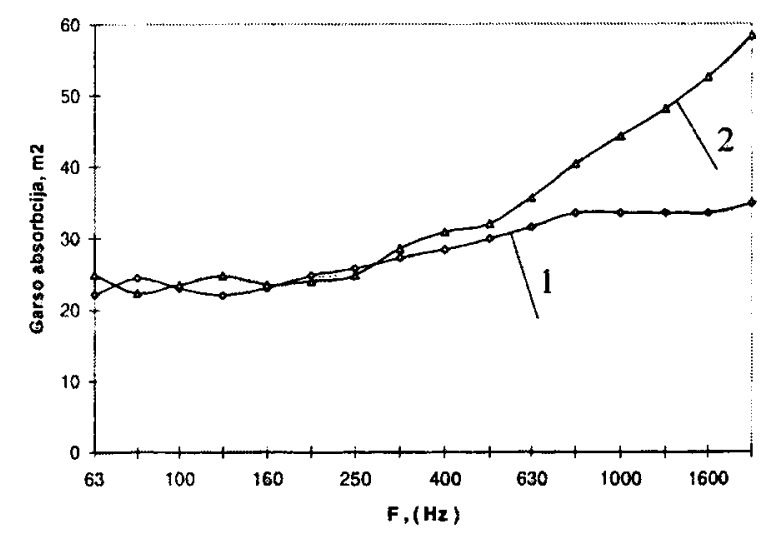

8 pav. Realios salès (1) ir jos modelio (2) garso absorbcijos, apskaiciuotos iš reverberacijos laiko aproksimuojant garso lauko slopimą nuo $-5 \mathrm{iki}-35 \mathrm{~dB}$, dažninè priklausomybé

Fig 8. The dependence of the sound absorption calculated of the reverberation time approximation of the sound decrease from -5 to $-35 \mathrm{~dB}$ in the real hall (1) and its model (2)

Garso absorbcijos kitimo charakteris yra toks pats, kaip ir absorbcijos koeficientu. Iki $500 \mathrm{~Hz}$ realios salès ir jos modelio absorbcijos skiriasi labai nedaug - tik $1-2 \mathrm{~m}^{2}$. Augant dažniui šis skirtumas dideja iki $5-20 \mathrm{~m}^{2}$.

Vienas iš pagrindiniu subjektyvių muzikos skambèjimo rodikliu yra aiškumo indeksas. Jo reikšmès yra susijusios su garso atspindžių struktūra ivairiais laiko intervalais. Nefiltruotam signalui realios salès aiškumo indeksas yra $-5,6 \mathrm{~dB}$, o jos 
modeliui $-4,9 \mathrm{~dB}$ ir šis skirtumas yra nedidelis. Šio rodiklio dažninès priklausomybès pateiktos 9 paveiksle.

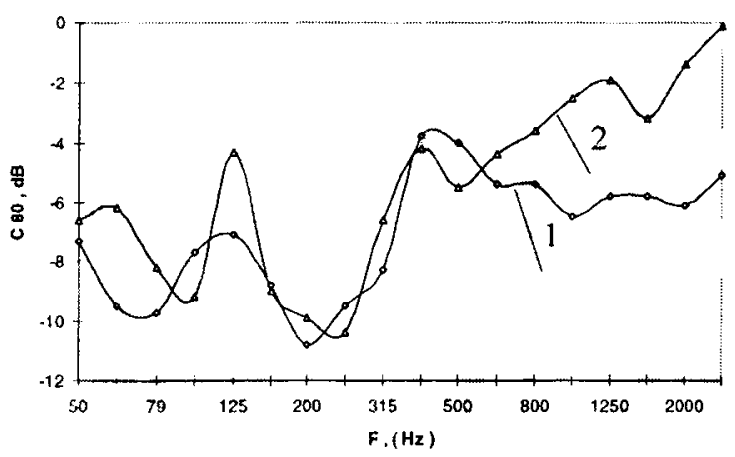

9 pav. Realios salès (1) ir jos modelio (2) muzikos skambejjimo aiškumo indekso dažniné priklausomybé

Fig 9. The frequency dependence of music clarity index in the real hall (1) and its model (2)

Salès ir jos modelio aiškumo indeksai visiškai artimi dažnių diapazonui esant $630 \mathrm{~Hz}$ ir tik esant 63 ir $125 \mathrm{~Hz}$ rezultatai skiriasi apie 1,5 dB. Didejant dažniui skirtumas didejja del minètos garso absorbcijos ore.

\section{Išvados}

1. Dažnių intervalui esant nuo 63 iki $500-630 \mathrm{~Hz}$ filtruoto signalo reverberacijos laikai, aproksimuoti pagal slopimą nuo 0 iki $-10,-20,-30$ ir nuo $-5 \mathrm{iki}-35 \mathrm{~dB}$, gaunami visiškai artimi realios salès reverberacijos laikams. Jie skiriasi tik 4-14\%. Tai rodo, kad panaudotos modeliui medžiagos yra identiškos realios salès medžiagoms.

2. Nefiltruoto signalo garso lauko slopimas realioje saleje ir jos modelyje yra beveik visai vienodas per pirmas ir paskutines $400 \mathrm{~ms}$. Tarpiniame laiko intervale, apytikriai nuo 500 iki $3000 \mathrm{~ms}$, garso lauko slopimas modelyje yra tik $1-3 \mathrm{~dB}$ didesnis negu tikrovejje.

3. Realios salès ir jos modelio garso absorbcija dažnių diapazonui esant $500 \mathrm{~Hz}$ skiriasi tik 1-2 $\mathrm{m}^{2}$.

4. Realios salès modelyje galima tirti tokius akustinius reiškinius, kaip garso lauko difuziškumas, pasikartojantys aidai, oro tũrio rezonansai ir kt., t. y. procesus, kurių apskaičiuoti teoriškai neimanoma.

\section{Literatūra}

1. D. Fitzroy. Reverberation formula which seems to be more accurate with non unform distribution of absorption // J. Acoust. Soc. Am., 31, 893, 1959.

2. W. Sabine. Amer. Arch. and Building News. New York, 1900.

3. C. F. Eyring. Reverberration time in "dead" rooms // J. Acoust. Soc. Am., 1, 217, 1930.

4. A. Millngton. A modified formula for reverberation // J. Acoust. Soc. Am., 69, 1932.

5. Л. Макриенко. Акустика помещений общественных зданий. М.: Стройиздат, 1986. 172 с.

6. H. Winkler. Die Kompensation der su grosen Luftabsorption bei raumakustishen Modellmessungen mit Echogrammen // Hochfrequenztechnik und Elektroakustik. 1964, V. 73, N. 4, S. 132-138.

Iteikta 19981120

\section{SIMILARITY BETWEEN ACOUSTIC INDICATORS OF AN REAL HALL AND ITS MODEL}

\section{J. Stauskis}

\section{S u m mar y}

The similarity between acoustic indicators of an real hall and its model has been examined. A rectangular hall is $13.6 \mathrm{~m}$ long, $10.7 \mathrm{~m}$ wide and $7.0 \mathrm{~m}$ high. Its floor and ceiling are horizontal. The hall has plastered walls, parquet floor, and reinforced-concrete-slab ceiling. Thus, all surfaces of the hall are made of materials that reflect sound well.

A hall model scaled 1:25 was made. The floor and ceiling of the model were made of fabric-based laminate and the walls were made of veneer $8 \mathrm{~mm}$ thick, lacquered three times. Therefore, the materials used to produce the model are similar to those of the real hall by their sound absorption properties.

A 9 calibre sound pistol was used as a sound source for the investigations in the real hall. The sound signal was stored in the computer memory via a $1 / 2$ ' microphone, an amplifier and an analog-to-digital converter, then analysed by means of a acoustical signal analysis program developed by us. The signal was analysed within the frequency range of $50-5000 \mathrm{~Hz}$. The main objective and subjective acoustical indicators of the hall were calculated using this program.

A spark sound source was used for the experiments with the hall model. It was thrust through a hole in the floor in order to improve the radiation directivity diagram. The position of the sound source and a $1 / 4$ 'microphone was the same in the real hall and its model. The signal was fed from the microphone to the amplifier, then to the analog-to-digital converter and recorded in the computer memory. The signal may be recorded via several different buffers allowing to record 
signals of varied length. The range of the frequencies investigated was from 1250 to $50000 \mathrm{~Hz}$, the model scale being 1:25. The signal digitization frequency was $166.6 \mathrm{kHz}$ and the digitization time was $6 \mathrm{mks}$.

The decrease of the sound field of a non-filtered signal is of a similar nature during the first and the last $400 \mathrm{~ms}$, i e during the early and the late periods of decrease. In the intermediate period, approximately from 500 to $3000 \mathrm{~ms}$, the sound field decrease in the model exceeds the one in the real hall by only $1-3 \mathrm{~dB}$. In the real hall, the sound field decrease is close to the straight line up to $2500 \mathrm{~ms}$, while in the model - up to $1000 \mathrm{~ms}$ only, and the decrease is faster than in actual practice. The further field decrease has the character of a curve and the diffusive properties of the field are impaired. These results show that the sound field decrease in the real hall and in the model is quite similar.

Investigations show that the sound field decrease in the real hall and in the model is almost analogous when the decrease is approximated every $10 \mathrm{~dB}$ from 0 to $30 \mathrm{~dB}$. The reverberation time difference is $0.16-0.5 \mathrm{~s}$ and is lower than $10 \%$. As the field decrease is approximated from -5 to $-35 \mathrm{~dB}$, the reverberation time of the model exceeds that of the real hall by about $1 \mathrm{~s}$, which makes up about $15 \%$.

The difference between the early reverberation time of the real hall and its model is only $-0.2-0.8 \mathrm{~s}$ even up to $500 \mathrm{~Hz}$. This is mainly determined by the air sound absorption in the model at the ultrasound frequencies.
As the sound field decrease is approximated from 0 to $-30 \mathrm{~dB}$ and from -5 to $-35 \mathrm{~dB}$, the difference between the reverberation time of the hall and its model in the frequency range up to $500 \mathrm{~Hz}$ is slight, only $0.2-0.9 \mathrm{~s}$, which is less than $15 \%$.

The character of change in the sound absorption is analogous to that of the sound absorption coefficients. In the range up to $500 \mathrm{~Hz}$, the sound absorption of the real hall and its model differs by 1-2 $\mathrm{m}^{2}$ only. As frequency increase, the difference reaches $-20 \mathrm{~m}^{2}$.

For a non-filtered signal, the music sound clarity in$\operatorname{dex} C 80$ is $5.6 \mathrm{~dB}$ for the real hall and $4.9 \mathrm{~dB}$ for the model.

Vytautas STAUSKIS. Doctor Habil, Professor. Dept of Building Structures. Vilnius Gediminas Technical University (VGTU), Saulètekio al. 11, LT-2040 Vilnius, Lithuania.

Doctor (1974). From 1974 at VTU Department of Building Structures. Research visits: Moscow Civil Engineering Institute, Sankt-Petersburg Politechnic Institute. Research interests: experimental testing of halls by primary hall models and on site, computer simulation of theoretic tasks, wave diffraction and reflections, direct sound and subjective acoustic indicators, large-dimension resonance structures, early attenuation of acoustic field and its relation to hall acoustics. 